\title{
Društvena teorija i postnormalna znanost
}

\author{
Božo KOVAČEVIĆ
}

Visoka škola međunarodnih odnosa i diplomacije Dag Hammarskjöld, Zagreb

bkovacevic55@gmail.com

- Alex Law. Social Theory for Today: Making Sense of Social Worlds. Los Angeles: SAGE, 2015, 344 str.

Alex Law, profesor sociologije na Sveučilištu Abertay u Škotskoj, napisao je - kako to i njezin naslov sugerira - vrlo ambicioznu knjigu. Ona pokušava uobličiti društvenu teoriju koja bi odgovarala složenoj stvarnosti suvremenog svijeta. Taj svijet je od vremena nastupanja prosvjetiteljstva i modernosti obilježen krizom. Različite teorije o društvu pokušaji su pronalaženja odgovora na pitanja o skrivenim zakonima u skladu s kojima se odvijaju naizgled kaotične promjene društvene zbilje.

Mnoštvo teorija o društvu i - za razliku od prirodnih znanosti - nepostojanje jedne neupitne paradigme navode na pomisao o krizi društvene teorije. Takvo stanje posljedica je narcizma malih razlika i teorijskog harangiranja (theory-baiting) koje se provodi sa svrhom da se pod svaku cijenu pokaže da suparnička teorija nije prihvatljiva. Umjesto takvog pristupa Law predlože da se u relevantnim društvenim teorijama prepozna ono vrijedno čime svaka od njih pokušava odrediti probleme društvene zbilje. Tako bi se mogli prepoznati dugoročni obrasci teorijskog razvitka. »Nužna dionica u teorijskom napretku je razumijevanje protivnika u bilo kojoj teorijskoj raspravi kao mogućih saveznika, ne kao neprijatelja koji trebaju biti uništeni, jer su oni možda otkrili prave probleme koji zahtijevaju ozbiljnu sociološku analizu« (Law, 2015: 299). U istom duhu on konstatira da je isticanje fatalnih pogrešaka u suparničkim teorijama »skolastička igra koja nužno izaziva krizu« (Law, 2015: 301).

Nasuprot pretjeranoj specijalizaciji i fragmentaciji sociologije, Law se zauzima za teorijsku sintezu. Ta sinteza ipak ostaje nejasna jer ona ne podrazumijeva standardni pojmovni vokabular ni standardnu metodologiju. Temeljem načina na koji obrađuje pojedine primjere iz tradicije društvene misli i referenci na koje se poziva u svojim interpretacijama možemo zaključiti da bi se ta sinteza zasnivala na Bourdieuu i poststrukturalističkom/postmodernističkom razumijevanju teorije kao načina konstruiranja predmeta koji se proučava. Pomalo u neskladu s najavom iz naslova knjige da će ponuditi društvenu teoriju za današnji svijet, Law zapravo nudi još jedno od čitanja priznatih i nepriznatih klasika društvene misli.

Ta povijest društvene misli opisana je u trinaest zaokreta, od Comteova pozitivističkog i Marxova zaokreta do, u konačnici, relacionističkog zaokreta Norber- 
ta Eliasa i Pierrea Bourdieua. Teme i autori koje se redovito smješta u tradiciju marksističke misli Law razvrstava u nekoliko zasebnih cjelina. Tako su Gramsci i Lukacs predstavljeni u poglavlju o ideološkom zaokretu, Walter Benjamin kao primjer modernističkog zaokreta, mislioci Frankfurtske škole Horkheimer i Adorno kao kritički zaokret, a ta dvojica su zajedno s Habermasom uzeti i kao primjeri zasebnoga negativnog zaokreta, dok je Henriju Lefebvreu posvećeno poglavlje o zaokretu svakodnevice. U drugoj polovini, onoj nemarksističkoj, obrađeni su osim već spomenutih Comtea, Eliasa i Bourdieua - Weber i Simmel kao primjeri Nietzscheovog zaokreta $u$ društvenoj teoriji, Neurath kao izvođač refleksivnog i Merleau-Ponty kao primjer tjelesnog zaokreta. Pragmatičkim zaokretom nazvano je poglavlje posvećeno društvenoj teoriji u Americi. Kao da oni ne pripadaju europskom kulturnom kontekstu, posebno poglavlje, nazvano kulturni zaokret, posvećeno je društvenim misliocima u Francuskoj i Britaniji.

Već pri površnom uvidu u knjigu čitatelj će se opravdano zapitati zašto Law nije detektirao, primjerice, frojdovski zaokret u društvenoj teoriji. Utjecaj Freuda, kako na marksiste od Reicha do Fromma, Marcusea i Theweleita, tako i na teoretičare drukčijih usmjerenja, nije bio ništa manje zamjetan nego utjecaj Nietzschea. Jednako bi opravdana bila primjedba da je ostao nezamijećen lingvistički preokret u društvenoj teoriji koji je, u kombinaciji s elementima učenja Marxa, Freuda i Nietzschea, omogućio procvat poststrukturalističke teorije koju Law očito uvažava i u mnogome se oslanja na nju. Čitatelj će zamijetiti da se u poglavlju »Tjelesni zaokret: Maurice Perleau-Ponty« kao i u poglavlju »Pragmatički zaokret: društvena teorija u SADu« inzistira na važnosti Husserlove fenomenologije za razvoj tih smjerova društvene teorije, ali nema poglavlja posvećenog Husserlu i mogućem njegovu zaokretu u društvenoj teoriji. No, više od svega, zamjetno je nespominjanje biološkog zaokreta $\mathrm{u}$ društvenoj teoriji. Herbert Spencer, kao jedan od klasika društvene misli koji je oblikovao biologističku koncepciju društva, u ovoj knjizi nije dobio svoje poglavlje, a Charles Darwin nije ni spomenut, premda je njegova teorija najzaslužnija za pravu eksploziju istraživanja na području sociobiologije, čiji trijumf je, nakon više desetljeća žestokog osporavanja, proglašen još početkom 21. stoljeća (Alcock, 2001).

Dakako, svatko razuman zna da nitko, ma koliko načitan bio, ne može pročitati baš sve i da se uvijek može pronaći nešto što je namjerno ili nenamjerno izostavljeno. No, ako netko ima ambiciju napraviti sintezu društvene teorije - dakle ako netko ima anakroničnu hegelijansku ambiciju da pomiri proturječja između različitih teorijskih koncepcija i da pronikne u bit društvene zbilje i logiku razvoja društvene teorije - onda je opravdano postaviti pitanje ponajprije o prešućivanju teoretičara i teorija društva koje su se razvijale pod utjecajem biologije. Zauzet prevladavanjem narcizma malih razlika, Law kao da je odlučio izbjeći suočavanje s pravim, velikim razlikama i ozbiljnim pitanjima koja se otvaraju u području susreta i sukoba genetike, biologije, psihologije, sociologije i politike.

Sasvim predvidljivo s obzirom na naznačene ambicije i osnovne postavke, Law je konstatirao da osnivač sociologije i propovjednik pozitivne filozofije Auguste Comte nije bio pozitivist u suvremenom značenju tog pojma. Dok se danas smatra da pozitivizam inzistira na primjeni ontologije, epistemologije i metodolo- 
gije prirodnih znanosti na proučavanje društva, Comte je uspostavio sociologiju kao znanost nad znanostima koja se »razlikuje od prirodnih znanosti teorijom, metodom i predmetom« (Law, 2015: 32). Law, međutim, ne naglašava dovoljno da je Comte - u potrazi za stabilnošću koja je iščeznula s pojavom liberalne kritike tradicionalnih institucija - predlagao reformu zdravog razuma u interesu poretka $\mathrm{i}$ napretka, a u tome bi ključnu ulogu trebala imati nova religija, neka vrsta katolicizma bez kršćanstva.

Law je propustio da i Comtea pročita u svjetlosti uvida Nietzscheove filozofije o volji za moć, kako je protumačio druge klasike sociologije. Nakon neuspjeha u politici, Comte je koncipirao novu znanost koja bi trebala biti iznad svih ostalih znanosti i predložio novu religiju u okviru koje bi se propovijedala njegova filozofija. Ne znam kako autoru nije palo na pamet da u tako koncipiranoj Comteovoj teoriji vidi ostvarenje volje za moć kakvu, recimo, iskazuje pripovjedač koji u svojim djelima pobjeđuje i ubija ljude s kojima u stvarnom životu nikako ne izlazi na kraj. Mislim da bi takav ironično-psihološki pristup Comteovu opusu bio produktivniji nego što je Lawov pokušaj da Comtea rehabilitira kao nepozitivističkoga društvenog teoretičara. Sklon sam prihvatiti stajalište o Saint-Simoneu (kojega Law spominje, ali ne uvrštava u svoj panteon društvenih mislilaca) i Comteu prema kojemu su »njihovi spisi bili suviše spekulativni i metafizički da bi ih se smatralo prethodnicima onoga što se označava bilo kao 'pozitivizam' bilo kao 'sociologija' u modernoj raspravi« (Gordon, 1991: 411). Law govori o tome da je Comteov pozitivizam »ponudio utopijsku viziju društvene stabilnosti« (Law, 2015: 33) i da je svoju organsku doktrinu, koja je pozitivna i konstruktivna, suprotstavio kritičkoj doktrini koja je destruktivna i negativna. Ta kritička teorija koja je odigrala pozitivnu ulogu u rušenju starog, metafizičkog sustava onemogućuje uspostavu novog poretka i napredak. Drugim riječima, Comte je ocijenio da liberalizam ne jamči društvenu stabilnost i suprotstavio mu konzervativizam. Comte daje uvjerljivu potvrdu konstatacije da »društvena teorija ima antiliberalizam u svojim genima« (Turner, 2008: 562).

Marxov zaokret je nedvojbeno najdalekosežniji. Da je pola svoje knjige naslovio kao Marxov zaokret, Law ne bi pogriješio jer on doista ponajviše prikazuje različite mislioce koji pripadaju tradiciji marksističke misli. Kritika je glavno obilježje Marxova opusa, a stalna kriza je ključna odrednica zbilje kapitalističkog društva. Liberalizam kao glavni idejni promicatelj kapitalizma ujedno je i glavni predmet Marxove kritike, ali on - za razliku od Comtea - nije ni pomislio da bi restauracija predmodernih institucija mogla biti odgovor na nestabilnost, slučajnost i neizvjesnost modernoga kapitalističkog vremena. Ukazavši na neusklađenost između stvarnih društvenih odnosa i oblika društvene svijesti koji opravdavaju te nepravedne odnose kao jedino moguće i neizbježne, Marx revoluciju vidi kao rješenje suprotstavljenih društvenih interesa i kao put prema usklađivanju odnosa između zbilje i ideoloških predodžbi o njoj. Predviđanja o radničkoj klasi kao povijesnom subjektu koji će u dogledno vrijeme reificirane odnose kapitalističkog društva preobratiti u takve odnose u kojima ljudi jedni drugima nisu sredstva za ostvarivanje sebičnih interesa pokazala su se pogrešnima. No kritički potencijal Marxovih teorijskih uvida ostao je kao trajna baština društvene misli. Kritička teorija - jedna 
od onih inačica marksizma koje su odustale od planiranja revolucije - zaokupljena je utvrđivanjem odnosa dominacije i načina njihove reprodukcije te iznalaženjem puteva za njihovo prevladavanje angažmanom na objašnjavanju i upućivanjem na politički rad unutar demokratskih institucija.

Zanimljivo je, dakle, da Law gotovo cjelokupnu marksističku tradiciju 20. stoljeća prikazuje u okvirima poglavlja o pet različitih zaokreta koje ne imenuje marksističkima, a u poglavlju koje je naslovljeno kao Marxov zaokret, osim samoga Marxa, prikazuje još samo ruskog revolucionara, političara i teoretičara Nikolaja Buharina. Buharinova knjiga Historijski materijalizam: sustav sociologije objavljena je 1921. godine. Potpuno suprotno duhu Marxova opusa, koji kritiku svega postojećeg inaugurira kao trajnu praksu u analizi društvenih odnosa, Buharinova knjiga je pokušaj da se marksizam prikaže u okviru krajnje pojednostavljenog katekizma i apologije boljševičke koncepcije društva kao ostvarenja Marxovih zamisli. Law ni na koji način ne obrazlaže zašto u tom poglavlju nije bilo mjesta za Plehanova i ni za koga iz tradicije austromarksizma, a opširno je - kao da je riječ o djelu koje bi se moglo tretirati ravnopravno s Marxovim opusom - prikazana knjiga koja je, prema jednoj ocjeni »dokument zapanjujućeg teorijskog primitivizma« (Kolakowski, 1985: 69). Law ne zamjećuje da je Buharin pokušao napraviti kanonizaciju marksističkog učenja usporedivu s kanonizacijom vlastita opusa koju je napravio Comte proklamirajući novu pozitivističku religiju.

Sam Max Weber svjedočio je o stanovitom utjecaju Nietzschea na sebe osobno i općenito na pripadnike tog naraštaja. No, za razliku od Georgea Simmela, nije se deklarirao kao ničeanac (činjenica, pak, da Durkheim - premda se bavio sociologijom religije i sociologijom morala - ni na koji način nije bio pod Nietzscheovim utjecajem rezultirala je time da taj klasik društvene misli nije uvršten ni u jedan od zaokreta kojima se Law bavi ostavljajući otvorenim pitanje da li je time Law poručio da Durkheim baš ničim ne bi mogao pridonijeti društvenoj teoriji našega vremena). Ni literatura o Weberu ne prešućuje da je Nietzsche nerijetko bio neizrečena referentna točka u njegovim radovima, osobito u sociologiji religije. Weberov dug Nietzscheu tiče se procesa sekularizacije koji je utjecao na raširenost osjećaja besmislenosti i na potkopavanje legitimnosti društvenih institucija. Isto tako Nietzscheov utjecaj vidljiv je u tretmanu povijesti kao neprestanog nadmetanja različitih skupina kao izraza volje za moć i srdžbe dotad deprivilegiranih društvenih slojeva (Turner, 1992: 188). No, time nije rečeno da Weber, osim s historijskim materijalizmom, nije polemizirao i sa samim Nietzscheom (Ringer, 2004: 144). Komentirajući Nietzscheu i Weberu zajedničke opservacije o židovsko-kršćanskoj religiji kao o religiji slabih koja je na povijesnu scenu iznijela srdžbu masa i tiraniju prosječnosti, ipak je nemoguće ne zamijetiti važne razlike između njih. Kad je riječ o srdžbi masa, Weber »nudi neostrašćenu školničku analizu dok Nietzsche pruža njezinu strasnu denuncijaciju. Weber misli da je to mali ali važan sociološki pojam; Nietzsche smatra da je to temeljno metafizičko/etičko motrište koje je odgovorno za stvarnu i potpunu propast zapadne civilizacije« (Adair-Toteff, 2015: 125-126).

Law konstatira da je Weber zapravo ničeanac jer su »obojica dijelili zaokupljenost moralnom kritikom kapitalističke modernosti« (Law, 2015: 74). Dakako, i 
Law mora konstatirati da je, za razliku od Webera, »Nietzscheova interpretativna strategija odbila razviti metodičku znanstvenu teoriju društvenih procesa i struktura« (Law, 2015: 73) i da je Weber - za razliku od Nietzschea koji je bio gorljivi i netolerantni propovjednik svojih ideja - »bio spreman tolerirati vrijednosti nepomirljive s njegovim vlastitim liberalnim nacionalizmom i etikom odgovornosti, uključujući anarhizam, pacifizam i socijalizam« (Law, 2015: 75). Dakle, i Law konstatira da između Webera i Nietzschea postoje bitne svjetonazorske i političke razlike pa ipak je Webera, zajedno sa Simmelom, prikazao kao primjere Nietzscheova zaokreta u društvenoj misli.

Meni se čini da je ta odluka uvjetovana ponajprije stanovitim poststrukturalističkim pomodarstvom koje je anglosaksonski svijet zahvatilo s određenim faznim pomakom u odnosu na Francusku. Ti teoretičari - usmjereni na otkrivanje odnosa moći u samom diskursu i na radikalnu dekonstrukciju svakog oblika prosvjetiteljstva kao načina dominacije - Nietzschea čitaju samo kao zagovornika perspektivizma i prevrednovanja svih vrijednosti. Njihova optika ne zapaža totalitarističke potencijale u Nietzscheovu prizivanju nadčovjeka. Da je bio manje zaveden poststrukturalističkom modom koja Nietzschea svrstava i gotovo amalgamira zajedno s Marxom, Freudom, de Saussureom i Lacanom, Law bi možda mogao otvorenije pristupiti utvrđivanju sličnosti i razlika između Nietzschea i Webera. Nietzscheov se zaokret - utemeljen na stajalištu da je Nietzsche za društvenu teoriju važniji od Webera - dogodio tek u drugoj polovici 20. stoljeća, a nipošto ne s Weberom i Simmelom, kako to tvrdi Law. Jedan drugi sociolog - koji se poziva na Derridu tvrdeći da je sociologija samo jedan od primjera literarne prakse, ali se on u puno većoj mjeri oslanja na marksističku tradiciju potrage za socijalnom pravdom - konstatirao je da bi Webera i Durkheima, da su živi, vjerojatno smatrali liberalima »i oni bi mogli glasati za Franklina Roosevelta tridesetih ili za Billa Clintona devedesetih godina« (Agger, 2004: 50). S obzirom na to koliko ga je pogađao i do očaja dovodio nihilizam proizašao iz činjenice da je Bog mrtav, za Nietzschea bi se s velikom vjerojatnošću moglo pretpostaviti da bi više razumijevanja pokazao za pojavu nadčovjeka u politici negoli za bilo koji oblik institucionalizirane demokracije i racionalnog autoriteta.

Možda najzorniji primjer autorova nastojanja za prevladavanjem teorijskog harangiranja nalazimo u poglavlju »Pragmatički zaokret: društvena teorija u SAD-u«. Uvod u taj pragmatički zaokret napravio je Alfred Schütz popularizirajući primjenu Husserlove fenomenologije na proučavanje društva, ali tako da je svakodnevni život stavio u središte proučavanja za razliku od Husserla koji ga je, analizirajući i opisujući oblike svijesti, stavio u zagradu. Etnometodologija Harolda Garfinkela predstavljena je tako kao da se njezina pojava može zahvaliti fenomenologiji premda je ona, umjesto na pojavna svojstva iskustva, »prebacila analizu svakodnevnog života na strukturiranje praksi kroz nezamijećena pravila i procedure« (Law, 2015: 236). Sama filozofska fenomenologija nerijetko je bila zbunjujuća pa je bilo i onih koji su »zaključili da filozofija koja ne može definirati svoje vlastito područje ne zaslužuje rasprave koje su se o njoj vodile« (Audi, 1999: 698). I u rječnicima sociologije može se naći tvrdnja da fenomenologija »nije bitno utjecala na sociologiju u cjelini« (Turner, Aberchrombie i Hill, 2008: 83). Law nije uspio objasniti zašto 
su fenomenologija i etnometodologija toliko važne za suvremenu društvenu misao. Predstavljajući autore i djela $\mathrm{s}$ tih područja on koristi njihove termine i sintagme ne objasnivši ih dostatno i ne stavivši ih u jasan odnos s drugim koncepcijama o kojima piše i ne uspostavivši kontekst u kojem oni imaju smisla. Dok čitajući leksikografske natuknice u rječnicima filozofije i sociologije čitatelj može steći predodžbu o čemu se u tim teorijskim koncepcijama radi, kad čita obradu tih tema koju prezentira Law, nije sasvim jasno o čemu je riječ.

Američki pragmatizam - čije predstavnike relevantne za suvremenu društvenu teoriju Law, u potpunosti preuzimajući Millsove teze iz knjige Sociologija i pragmatizam, vidi u Peirceu, Jamesu i Deweyu-stavljen je u isto poglavlje s fenomenologijom i etnometodologijom. Ni nakon pažljivijeg čitanja tog poglavlja nije sasvim jasno zašto Law smatra da su te tri teorijske koncepcije srodne, odnosno zašto su fenomenologija i etnometodologija podvedene pod pragmatički zaokret. Kad kaže da je glavna vrijednost pragmatizma u tome što on »odbacuje bilo koju apsolutnu ideju istine u korist mnogo realističnijeg bavljenja prihvatljivim objašnjenjima koja imaju smisao prakse u konkretnim situacijama« i kad kaže da je pragmatizam »nastojao staviti točku na apstraktni dualizam filozofskog racionalizma: tijelo i um, subjekt i objekt, struktura i djelovanje« (Law, 2015: 241), Law iznosi važne filozofske konstatacije. No, da bi bilo sasvim jasno zašto on misli da pragmatizam »daleko od toga da bi bio samo teorija učinkovitosti, kako se često pretpostavlja, [jer] ima etičku i politički važnost« (Law, 2015: 241), to bi stajalište trebalo objasniti na prostoru nešto većem od jedne stranice na kojoj je, ukratko prepričavši sadržaj već spomenute Millsove knjige, prikazao učenja sve trojice već spomenutih američkih pragmatista. Na toj jednoj stranici spomenuti su ili citirani još Durkheim, škotska filozofija zdravog razuma, Sellars, Weber, Bernstein, Arendt i Gadamer i to nakon što su na prethodnoj stranici spomenuti Mead, Freud, Durkheim, Elias, Foucault, Beck, Giddens, Wilkie, McKinnon, Blumer i Joas. Spominjanje imena i citiranje dijelova rečenica ili navođenje termina koje su ti autori koristili u većoj mjeri zamagljuje negoli što razjašnjava ono što sam Law želi reći.

$\mathrm{Na}$ kraju tog poglavlja, nakon što je ukratko raspravio sociologiju svakodnevnog života Ervinga Goffmana i feminističke teorije o društvu, Law je zaključio da društvena teorija »ako je ispražnjena od povijesnog, moralnog ili komparativnog konteksta, onda uz nju prianja nekritički konformizam. Ipak je jasno da su, daleko od toga da bi bili nekritičke apologije, fenomenologija i pragmatizam generirali neke od resursa koji su potrebni za kritičku teoriju društva danas« (Law, 2015: 254). I u tim zaključcima Law se u potpunosti oslanja na Millsa kao teoretičara koji je cijenio pragmatizam jer je ovaj povezivao teoriju s praksom. No taj svoj očit interes za aktivističku dimenziju društvene teorije Law nije uspio izraziti na tako jednostavan i razumljiv način kojim je Mills to učinio u svojim knjigama. Law se probija kroz nepregledno mnoštvo citata i posuđuje termine, sintagme i ideje stvarajući od njih poprilično nepregledan mozaik kojim kao da želi pokazati da drugi autori govore ono što bi on sam htio reći.

Pokušaj izgradnje društvene teorije za suvremeni svijet, kakvog se poduhvatio Law, podsjeća na Millsova nastojanja u knjizi Sociološka imaginacija da afirmira 
sociologiju kao društveno angažiranu djelatnost nasuprot već uhodanoj praksi izgradnje akademske discipline sa strogo definiranim žargonom i skupom metodoloških pravila. Pravu primjenu sociološke imaginacije Mills ne vidi u produkciji znanstvenih članaka pisanih po uzoru na prirodne znanosti, koje može razumjeti samo uzak krug specijalista koji vladaju žargonom, nego kao odgovornu publicističku djelatnost namijenjenu širokoj čitateljskoj publici. Sociološka imaginacija, kako je vidi Mills, »nije samo jedna kakvoća svijesti u nizu suvremenih kulturnih senzibiliteta - to je upravo ona kakvoća čija šira i spretnija upotreba nudi obećanje da će svi takvi senzibiliteti - i, zapravo, sam ljudski razum - igrati veću ulogu u ljudskim poslovima« (Mills, 2000 [1959]: 15). Potpuno predan svom društvenom aktivizmu, Mills konstatira: »Svi društveni znanstvenici činjenicom svog postojanja uključeni su u borbu između prosvjetiteljstva i mračnjaštva. U takvom svijetu kakav je naš prakticiranje društvene znanosti je, ponajprije, prakticiranje politike istine« (Mills, 2000 [1959]: 178). Mills, očito, smatra da nema pravog razloga zbog kojega bi način pisanja o društvenim problemima i stil kojim pišu društveni znanstvenici trebao biti nerazumljiv i nepristupačan prosječnom čitatelju. Law ga u tome ne slijedi budući da tvrdi da »specijalizirani diskurs društvene teorije nije ponajviše povezan s namjernim opskurantizmom« (Law, 2015: 3). Law, dakle, smatra da se o složenoj stvarnosti društvenog života može pisati samo na jednako složen način. Vjerojatno zbog takvog shvaćanja nije Millsa prepoznao ponajprije kao jednog od začetnika tradicije politički osviještene sociologije - kojoj bi po ambiciji iznalaženja društvene teorije za rješavanje kriza našeg vremena i sam Law trebao pripadati - nego samo kao autora koji je afirmativno pisao o američkom pragmatizmu.

I Alvin Gouldner - kojega Law spominje u uvodnom dijelu svoje knjige, ali ga u poglavlju o američkoj društvenoj teoriji uopće ne spominje - pripada u red onih sociologa koji su discipliniranje u okvirima Parsonsova funkcionalizma smatrali pogubnim za sociologiju i sociologe. Komentirajući tadašnje stanje i trendove u američkoj sociologiji, Gouldner konstatira da »to sociologiji svojstveno podređivanje pojedinca skupini služi ne toliko kao podsjetnik ljudima što jedni drugima duguju, nego kao razlog za pristajanje na status quo, za poslušnost uspostavljenom autoritetu« (Gouldner, 1971: 508). I opet bismo u nastojanju da Law oblikuje kritičku društvenu teoriju za naše vrijeme mogli prepoznati njegovu srodnost i s Gouldnerom - osobito s Gouldnerovim inzistiranjem na refleksivnoj sociologiji koja se bavi »onim što sociolozi žele činiti i onim što, zapravo, oni stvarno čine u svijetu« (Gouldner, 1971: 489) - ali te srodnosti nema kad je riječ o načinu pisanja. Gouldner piše jednostavno i razumljivo, tako da ga može čitati što je moguće širi krug čitatelja, dok Law kao da se trudi biti razumljiv što je moguće manjem broju ljudi.

Moglo bi se primijetiti da Mills i Gouldner govore o sociologiji, a Law se bavi društvenom teorijom pa, stoga, možda on ne govori o istom predmetu kojim su se bavili ti američki sociolozi. Meni se čini da nema prevelike razlike u njihovu predmetu bavljenja i njihovim ambicijama. Mills i Gouldner nastojali su obraniti sociologiju kao vid tradicionalne kritičke društvene teorije od dominantnog trenda 
pretvaranja sociologije u pozitivističku problem solving znanstvenu disciplinu. Law pak, nakon što je razmotrio odnos društvene teorije, društvene filozofije i sociologije, dolazi do zaključka da bi, baš zbog njegove snažne povezanosti s naslijeđem socijalne filozofije, »termin 'društvena teorija' morao biti zamijenjen terminom 'sociološka teorija' kao prikladnijim za teorijski kondenzat samostalne empirijske znanosti« (Law, 2015: 7). Ako bismo pokušali odrediti što je to za Lawa društvena teorija, došli bismo do zaključka da ona obuhvaća tradicionalnu socijalnu filozofiju, neanalitičku filozofiju sociologije i sociološke teorije koje se ne oslanjaju na pozitivizam i metodologiju prirodnih znanosti. Da bi naglasio razliku spram spekulativne socijalne filozofije, Law inzistira na tome da društvena teorija »načelno ne bi smjela biti određena svojom unutarnjom logikom nego svojom usklađenosti s iskustvenim sadržajem« (Law, 2015: 8). Društvena bi teorija trebala odgovarati na pitanja o ključnim problemima života stvarnih ljudi, ponuditi objašnjenja o uzrocima i posljedicama društvenih i političkih zbivanja i predložiti rješenja za uočene probleme. Deklarativno, dakle, Law je blizak ambicijama američke kritičke sociologije. No, njegova je knjiga neka vrsta egzegeze izabranih tekstova klasika sociologije provedena kroz prizmu poststrukturalističkog čitanja. Rezultat je takav da se neki od tih klasičnih tekstova čine manje jasnima nakon te egzegeze, nego što oni zapravo jesu. Upoznajući nas s tim klasičnim autorima i tekstovima, Law nas upoznaje i s problemima njihova vremena, ali ne određuje sasvim jasno kako to može pomoći u rješavanu problema našeg vremena. Štoviše, osim načelnih odredaba o posvemašnjoj krizi modernosti, Law ne spominje specifične suvremene probleme za koje bi društvena teorija možda mogla ponuditi rješenja. Njegovi napori kao da se iscrpljuju u pokušaju sanacije posljedica duge povijesti teorijskog harangiranja. A to u konačnici stvara dojam da pred čitateljem ipak nije sociološka teorija motivirana zbivanjima u suvremenom svijetu i namijenjena onima koji su zainteresirani za rješavanje aktualnih problema, nego prilično apstraktna bezvremena filozofija za one koji o svemu spomenutom u knjizi već ionako sve znaju.

Mnoštvo je autora koji, kao i Law, nastoje oblikovati društvenu teoriju primjerenu zahtjevima današnjeg vremena. Meni se čini da su to uspješniji što su bliži načinu razmišljanja i stilu pisanja Millsa i Gouldnera. Ništa manje upućeni u povijest društvene misli i potankosti teorijskih prijepora negoli je to Law, oni svoje ideje o društvenoj teoriji za aktualno vrijeme prezentiraju na krajnje jednostavan način. Ben Agger jedan je od tih autora koji sam sebe opisuje kao marksističkoga kritičkog teoretičara i kao postmodernista. On upozorava da su to samo slogani »koji kao da misle umjesto nas«, dok je njemu, kao protivniku sloganiranja, više stalo »do kazivanja dobre priče koja čitatelju pruža ključ za ono što čitam i za oblikovanje mojih argumenata« (Agger, 2004: 3). Za njega sociologija je »stil pisanja koji stvara argumente; kao takva ona je retorika« (Agger, 2004: 2). Sociologija je izrasla iz nastojanja mislilaca 19. stoljeća da pronađu rješenja za patnje velikog broja ljudi, za ekonomsku nejednakost i za otuđenje. U međuvremenu postala je znanstvena disciplina sa strogo definiranim žargonom i metodološkim pravilima, ali je prestala tragati za odgovorima na probleme s kojima se većina ljudi sučeljava. On upozorava da »ne bismo trebali biti previše optimistični u vezi sa sposob- 
nošću metodologije da misli umjesto nas« (Agger, 2004: 76). Zbog toga se Agger zauzima za deprofesionalizaciju sociologije smatrajući je »literarnom perspektivom o odnosima između ljudskih iskustava i djelovanja u svakodnevnom životu i velikih institucija civilnog društva, politike, ekonomije, obitelji i medija« (Agger, 2004: 9). Ako sociologija ne uključuje i osobno iskustvo, primjerice sjećanje na doživljaj terorističkih napada na SAD 11. rujna 2001. godine, ako ne integrira biografiju i povijest, onda ona ne može obaviti svoju zadaću. Svatko, a ne samo profesionalac, može oblikovati sociološku teoriju jer je to »djelatnost osmišljavanja svakodnevnog iskustva i događaja tako da im daje oblik, ali isto tako uči od njih« (Agger, 2004: 162). Jasno se odredivši protiv sociologije kao znanstvene discipline, ali se ne odričući slobodoumnog skepticizma i empiricizma znanstvene metode i ne poričući važnost znanosti za napredak Europe i cijeloga svijeta, Agger sociologiju predstavlja kao više ili manje literariziranu verbalizaciju osobnih i kolektivnih iskustava i kao oblik politički angažirane publicistike.

Stajalište vrlo slično njegovom iznio je i Dietrich Rueschmeyer kad se zauzeo za artikuliranje takvih općih teorijskih okvira u sociologiji koji su »otvoreni za samsvoj-majstor teoretiziranje« (Rueschmeyer, 2009: 16). Anthony Elliott je jednako radikalno kritičan kad je u pitanju institucionalizirana sociologija i jednako otvoren u pozivanju da društvene teorije budu politički angažirane jer njihovu svrhu vidi u tome da »nude alternativna viđenja o tome kako bi se naši osobni i društveni životi mogli živjeti drukčije« (Elliott, 2014 [2009]: 346). Ni Donald Levine ne može zamisliti društvenu teoriju koja ne bi bila angažirana na demokratizaciji društva, a od društvenih teoretičara očekuje »da pokažu kako društveni teoretičari kao javni intelektualci mogu funkcionirati na uvjerljiv i konstruktivan način« (Levine, 2014: xxvii). Vjeran duhu Millsova sociološkog aktivizma, on kaže: »Moralno nadahnuti diskurs oslonjen na dobru sociološku spoznaju promiče prosvjećenije javne politike i zamisli za stvaranje boljeg života« (Levine, 2014: xviii).

Povjesničar američke sociologije Stephen Turner upozorava da je sociologija izgubila relevantnost koju je imala u vrijeme kad je nastajala i kad je bila zaokupljena problemima koji su zaokupljali i najširu javnost. Sociologija je započela »ne kao uspostava katedri i nacionalnih društava, nego kao forum za javnu raspravu o problemima temeljne prirode društva« (Turner, 2012: 350). Danas su pitanja o uskladivosti socijalizma i darvinizma, o prirodi društva i o procesima društvene evolucije i dalje predmet interesa javnosti, ali ne i većine sociologa i sociologije kao znanosti. Zbog toga se odgovora na ta pitanja poduhvaćaju nesociolozi, a sociologija gubi publiku i važnost u javnom životu. Odričući se rasprava o temeljnim pitanjima, sociologija je došla do situacije da »danas više nema ničega što bi sociolozi mogli reći o 'društvu' zbog toga što nema rasprave o tome« (Turner, 2012: 348). Od kraja 20. stoljeća sociologija preživljava samo zahvaljujući tome što se okrenula prema političkom aktivizmu i, ponajviše, prema rodnim i rasnim pitanjima. Ali takva sociologija ne može se smatrati znanošću, a sociolozi nisu znanstvenici nego zainteresirani eksperti. »Sociologija je oštećeni brend koji se povezuje s određenom vrstom politike i s određenom vrstom društvene intervencije« (Turner, 2014: 115). To partnerstvo i predanost određenim političkim uvjerenjima 
i ciljevima ne moraju biti neprijatelji činjenica. Oni predstavljaju odgovor na institucionaliziranu, visoku sociologiju i njezinu nezainteresiranost za suočavanjem s gorućim društvenim problemima. Takva institucionalizirana sociologija zaokupljena je »apstraktnom brigom za teorijsku istinu « i ne korespondira s interesima čitateljske publike. »Uloga teorije te vrste u sadašnjoj američkoj sociologiji, kao i onoga što sam nazvao 'većom sociologijom', sada je minimalna. Teorija je za 'upotrebu'« (Turner, 2014: 117). Drugi je autor anticipirao takvo Turnerovo viđenje kad je ustvrdio da društvena teorija »ne smije djelovati kao luđačka košulja, nego kao fleksibilni saveznik sposoban iznijeti na vidjelo uvide tamo gdje oni prije nisu bili dostupni« (Miles, 2001: 14).

Turner, vidjeli smo, kao da je time pronašao argumente u prilog američkog pragmatizma kojih se Law nije sjetio. No, Turner istodobno konstatira da je fragmentacija socioloških teorija - a Law to smatra jednim od ključnih problema suvremene društvene teorije koji on nastoji prevladati - posljedica interesa pojedinih istraživačkih zajednica ili društvenih skupina da aktualiziraju probleme koje oni smatraju važnima i da ih učine predmetom interesa politike. Dakle, pretpostavka da bi neka teorijska sinteza mogla pomiriti razlike između teorija artikuliranih za potrebe objašnjavanja i rješavanja problema specijalnih skupina čini se nerealnom. Stoga, tvrdi Turner, stvaranje takvih istraživačkih zajednica »koje odgovaraju ne na unutrašnji intelektualni razvoj područja nego na pritisak javnih pitanja ili potreba, karakteristika je postnormalne znanosti« (Turner, 2014: 118).

$\mathrm{U}$ tu sliku postnormalne znanosti uklapa se inzistiranje na tome da sociologija mora postati senzibilizirana za mnoge, ne samo ljudske objekte kao što su virusi, geni, cunami, hrana, kreditne kartice, kuće, kompjutori i otpad. Takav pristup podrazumijeva shvaćanje da »ništa nije konstituirano samo kao 'društveno', nego je stvarnost proizvedena u i pomoću praksi koje spajaju sve vrste agenata od kojih su samo neki ljudi« (Fuller, 2006: 7). Na sličan način i Olli Pyyhtinen vidi da je sociologiju u 21. stoljeću moguće održati na životu samo ako prestane biti disciplina o isključivo ljudskom svijetu. Potrebno je zamisliti novu sociologiju koja polazi od uvida da je svijet u kojem živimo istodobno ljudski i neljudski (Pyyhtinen, 2016). Dio nepregledne ponude pokušaja obogaćivanja sociološke imaginacije čini i punk sociologija koja želi razviti »oblik sociologije koji je poticajan za širu publiku, koji je relevantan i pristupačan i koji čini da ljudi osjećaju kao da se svatko može baviti sociologijom« (Beer, 2014: 5). Sumnjam da bi postojanje takve postnormalne društvene znanosti bilo uskladivo s jedinom normalnom društvenom teorijom kakvu bi, čini se, htio Law. Za razliku od njegova ambicioznog pokušaja pomirenja suparničkih društvenih teorija u jednu sintetičku i, zbog nastojanja da bude adekvatna složenostima društvene zbilje, izuzetno teško razumljivu teoriju, mnogi suvremeni autori nude sve raznorodnije pristupe i tekstualne prakse nadajući se da će na nereguliranom tržištu socioloških teorija pronaći barem ponekog kupca.

Zajedničko obilježje svih oblika kritičke, angažirane sociologije je polemičan odnos prema pokušaju da se sociologija izgradi kao jedinstvena paradigma po uzoru na prirodne znanosti. Parsonsov funkcionalizam i, općenito, pozitivizam bili su predmetom kritike Millsa, Gouldnera i suvremenih autora koje sam ovdje 
spomenuo. Oni su otvoreno polemizirali s činjenicom da je, odustavši od bavljenja temama od općeg interesa i prihvativši shematizaciju prikladnu za akademsku konzumaciju i institucionalizirano financiranje, sociologija krenula putem svoje društvene marginalizacije. Law ne polemizira s pozitivizmom. On svoja razmatranja o društvenoj teoriji za suvremeni svijet provodi i ne spominjući činjenicu da najveći dio literature koja se objavljuje pod nazivom sociologije ipak pripada $\mathrm{u}$ pozitivizam, u »način pisanja koji se, svojim primjerom, reproducira kao 'normalna znanost'« (Agger, 2004: 66). Čini se da je, osim već istaknutog nespominjanja biološkog zaokreta u društvenoj teoriji, potpuno ignoriranje sociološkog pozitivizma najveći nedostatak Lawove knjige. Suočavanje s pozitivizmom ne bi se moglo svesti na prevladavanje narcizma malih razlika. Između pozitivističke - i po pozitivističkom samorazumijevanju jedine - sociologije i različitih kritičkih i aktivističkih društvenih teorija razlike su, ako ne nepomirljive, sasvim sigurno velike. Utoliko bi pokušaj da se iskaže razumijevanje i za pozitivističke koncepcije društva za Lawa predstavljao daleko zahtjevniju i za čitatelja vjerojatno zanimljiviju zadaću. Za razliku od nekih pozitivista koji su se poduhvatili čitanja klasika sociologije ne bi li, primjenjujući logičku analizu jezika, izlučili formule kojima bi se jednom zauvijek odredili značenja i odnosi između pojmova korištenih u tim teorijama (Mueller, 2014; Tsilipakos, 2015), Law ničim ne pokazuje ni da je pročitao išta iz tog teorijskog korpusa niti da ga to uopće zanima.

Knjiga posvećena iznalaženju društvene teorije za naše vrijeme s jedne je strane izuzetno ambiciozna, a s druge je zaobišla pitanja koja bi je, da se suočila i s njima, učinila još ambicioznijom. Pokušaju da se raznorodne, filozofiji bliske i slične društvene teorije, sintetiziraju u jednu sveobuhvatnu suvremenu društvenu teoriju suprotstavljena je činjenica proliferacije socioloških koncepcija u okviru današnje postnormalne znanosti. Time se, izgleda, Lawov poduhvat pokazuje kao neuspješan. Zaobilaženje pak ključnih pitanja o odnosu genetike, biologije i društvenog svijeta kao i ignoriranje izazova koji pred kritičku društvenu teoriju postavlja dominantna pozitivistička produkcija u okviru sociologije, ovu knjigu čini nedovoljno ambicioznom. Staromodno pak shvaćanje društvene teorije kao nužno komplicirane, širim čitateljskim slojevima nerazumljive i rezervirane za posebno posvećene, uskratila je knjizi kvalitetu vrhunske publicistike koju imaju mnoga klasična i suvremena djela s područja društvene teorije. Zbog toga se može dogoditi da ovu knjigu čitaju samo oni koji to iz ovog ili onog razloga moraju, a ne i oni koji knjige čitaju ako im se na prvi pogled dopadnu.

\section{LITERATURA}

Adair-Toteff, Christopher (2015). Fundamenthal Concepts in Max Weber's Sociology of Religion. New York: Palgrave Macmillan.

Agger, Ben (2004). The Virtual Self. A Contemporary Sociology. Malden: Blackwell Publishing.

Alcock, John (2001). The Triumph of Sociobiology. Oxford: Oxford University Press. 
Audi, Robert (ur.) (1999). The Cambridge Dictionary of Philosophy. Cambridge: Cambridge University Press.

Beer, David (2014). Punk Sociology. New York: Palgrave Macmillan.

Elliott, Anthony (2014 [2009]). Contemporary Social Theory: An Introduction. Oxon i New York: Routledge.

Fuller, Steve (2006). The New Sociological Imagination. London: SAGE.

Gordon, Scott (1991). The History and Philosophy of Social Science. London i New York: Routledge.

Gouldner, Alvin W. (1971). The Coming Crisis of Western Sociology. London: Heinemann.

[Kolakowski, Leszek] Kolakovski, Lešek (1985). Glavni tokovi marksizma III. Beograd: BIGZ.

Law, Alex (2015). Social Theory for Today: Making Sense of Social Worlds. Los Angeles: SAGE.

Levine, Donald N. (2014). Social Theory as a Vocation: Genres of Theory Work in Sociology. New Brunswick: Transaction Publishers.

Miles, Steven (2001). Social Theory in the Real World. London: SAGE.

Mills, C. Wright (2000 [1959]). The Sociological Imagination. Oxford: Oxford University Press.

Mueller, Gert H. (2014). The Logical Foundations of Social Theory. Lanham: University Press of America.

Pyyhtinen, Olli (2016). More-than-Human Sociology: A New Sociological Imagination. New York: Palgrave Macmillan.

Ringer, Fritz (2004). Max Weber: An Intelectual Biography. Chicago: The University of Chicago Press.

Rueschmeyer, Dietrich (2009). Usable Theory: Analytic Tools for Social and Political Research. Princeton: Princeton University Press.

Tsilipakos, Leonidas (2015). Clarity and Confusion in Social Theory: Taking Concepts Seriously. Burlington: Ashgate.

Turner, Brian S. (1992). Max Weber: From History to Modernity. London i New York: Routledge.

Turner, Brian S., Aberchrombie, Nicholas i Hill, Stephen (2008). Rječnik sociologije. Zagreb: Jesenski i Turk.

Turner, Stephen (2008). »The Future of Social Theory«, u: Brian S. Turner (ur.). The New Blackwell Companion to Social Theory. Malden: Wiley Blackwell, str. 551-556.

Turner, Stephen (2012). »De-Intellectualizing American sociology: A history, of sorts«, Journal of Sociology, 48 (4): 346-363. doi: 10.1177/1440783312458226

Turner, Stephen (2014). American Sociology: From Pre-Disciplinary to Post-Normal. New York: Palgrave Macmillan. 